\title{
PENGARUH LAMA PENGUKUSAN DAN PENAMBAHAN LEVEL KADAR AIR YANG BERBEDA TERHADAP UJI PROKSIMAT DAN KECERNAAN PADA BUNGKIL KEDELAI, GAPLEK DAN POLLARD
}

\author{
EFFECTS OF STEAMING AND DIFFERENT MOISTURE CONTENT ON ANALYSIS \\ PROXIMATE AND DIGESTABILITY VALUE INCREASE IN SOY MEAL, TAPIOKA \\ FLOUR AND POLLARD
}

\author{
Saroh, S.Y., B. Sulistiyanto, M. Christiyanto dan C. S. Utama \\ Departemen Peternakan \\ Fakultas Peternakan dan Pertanian Universitas Diponegoro Semarang \\ Email: cahyasetyautama@gmail.com \\ Diterima: 19 Juni 2019, Direvisi: 18 Juli 2019, Disetujui: 31 Juli 2019
}

\begin{abstract}
ABSTRAK
Tujuan dari penelitian ini untuk mengkaji nilai nutrisi dari bahan pakan yang diberi tambahan air dengan level kadar air berbeda, yang di olah dengan pengukusan. Rancangan yang digunakan adalah rancangan acak lengkap (RAL) pola faktorial dengan lama pengukusan sebagai faktor 1 (A1 dan A2, 15 menit dan 30 menit) dan level penambahan kadar air sebagai faktor 2 (B1, B2, B3, 25\%, 50\% dan 50\%). Perlakuan dilakukan 2 kali ulangan kali. Hasil penelitian menunjukan tidak terdapat pengaruh interaksi, antara lama pengukusan 15 menit dan 30 menit dengan penambahan level kadar air $25 \%, 50 \%$ dan $75 \%$ terhadap parameter yang diamati. Simpulannya bahwa kombinasi lama pengukusan dan penambahan level kadar air tidak berpengaruh terhadap nilai kandungan proksimat dan kecernaan protein. Saran dari penulis adalah perlu adanya uji kecernaan in-vivo lebih lanjut, untuk mendukung hasil daripada penelitian ini.
\end{abstract}

Kata Kunci : Bungkil Kedelai, Pollard, Gaplek, Proksimat, Kecernaan Protein, Steaming

ABSTRACT

The purpose of the study, is to determine the nurtient value of several feedstuff that was given different moistire content and steaming duration as treatment. The experimental design in this study used a complete randomized design with two factors, of which are heating duration as the primary factor (A1 and A2, 15 minutes and 30 minutes) and moisture level as the secondary factor (B1, B2 and B, 25\%, 50\% and 75\%), with 2 repetition. The study shows no effect from the treatment on the value expressed, either from the duration of steaming or difference in moisture content. We recommend that further research by in-vivo digestibility analysis is needed to support the result of this research.

Keywords : Soybean Meal, Pollard, Tapioka Flour, Proximate, Digestability Value Increase, Steaming

Pengaruh Lama Pengukusan dan Penambahan Level Kadar Air yang Berbeda Terhadap Uji Proksimat dan 


\section{PENDAHULUAN}

Perlakuan terhadap limbah dapat dilakukan secara fisik, kimiawi, biologis maupun gabungan (Schiere dan Ibrahim, 1989). Perlakuan fisik berupa pemanasan melalui penguapan tekanan (steaming under pressure) berpengaruh terhadap komposisi kimia (Soejono et al., 1987). Pemanasan basah atau steaming, merupakan proses pengolahan bahan pakan secara fisik melalui proses pengukusan. Proses pemanasan dengan cara steaming akan mengakibatkan pelunakan terutama pada serat kasar di dalam bahan olahan dasar tanaman. Proses hidrolisis juga terjadi pada proses steaming, yaitu pemecahan komponen sel oleh senyawa air. Manfaat dari proses ini adalah memecahnya ikatan kompleks menjadi lebih sederhana, sehingga nutrient yang terbentuk lebih mudah dicerna oleh ternak dan membutuhkan lebih sedikit energi untuk mencerna (Soejono et al., 1987; Utama et al., 2017).

Bungkil kedelai merupakan limbah dari produksi minyak kedelai yang dapat digunakan sebagai bahan pakan sumber protein nabati. Kandungan gizi bungkil kedelai berdasarkan $100 \%$ BK adalah $51,9 \%$ PK; $5,1 \% \quad \mathrm{SK} ; 1,3 \%$ LK; 6,7\% abu dan 35,0\% BETN (Rasyaf, 1992). Pollard mengandung 18,5 \% PK (protein kasar); 9,78\% SK (serat kasar); 3,86\% LK (lemak kasar); 61,93 BETN (bahan ekstrak tanpa nitrogen); dan 5,93\% abu dalam konversi $100 \%$ bahan kering (Sutardi,1981). Gaplek mempunyai kandungan karbohidrat atau sumber energi yang tinggi, akan tetapi kandungan protein yang dimiliki sangat rendah yaitu sekitar $2 \%$.

Analisis proksimat merupakan pengujian kimiawi untuk mengetahui kandungan nutrient suatu bahan pakan atau pakan. Metode analisis proksimat pertama kali dikembangkan oleh Henneberg dan Stohman pada tahun 1860 di sebuah laboratorium penelitian di
Weende, Jerman (Hartadi et al., 1997). McDonald et al (1995) menjelaskan bahwa analisis proksimat dibagi menjadi enam praksi nutrient yaitu kadar air, abu, protein kasar, lemak kasar, serat kasar dan bahan ekstak tanpa nitrogen (BETN).

Kecernaan protein adalah total dari pencernaan protein murni dan protein by-pass (dalam bentuk asam amino) yang tersedia bagi hewaan untuk proses metabolism setelah pencernaan dan penyerapan pakan dalam saluran pencernaan (Gemman dan Sherrington, 1992 yang di sitasi oleh Ridwan, 2006).

\section{MATERI DAN METODE}

Materi yang digunakan dalam penelitian ini adalah bungkil kedelai, pollard, gaplek, dan akuades. Penambahan kadar air pada bungkil kedelai, pollard dan gaplek dengan level masing-masing sebanyak 25, 50 dan $75 \%$ dilakukan dengan metode Mirzah dan Filawati (2013), dimana bungkil kedelai, pollard dan gaplek yang telah diberi penambahan kadar air kemudian dipanaskan dalam autoclave pada suhu $121^{\circ} \mathrm{C}$, dengan durasi selama 15 menit dan 30 menit. Pollard kemudian dikeringkan di dalam oven pada suhu $70^{\circ} \mathrm{C}$ selama 8 jam untuk menghilangkan kadar airnya. Hasil kemudian dianalisis kandungan proksimat dan kecernaan proteinnya.

Data yang diperoleh, kemudian diuji menggunakan rancangan acak lengkap (RAL) pola faktorial 3 x 2, faktor pertama level kadar air (25, 50 dan $75 \%$ ) dan faktor kedua lama waktu pemanasan (15 dan 30 menit) dengan masing-masing 2 ulangan. Data dianalisis menggunakan analysis of variance / ANOVA untuk mengetahui pengaruh perlakuan terhadap parameter. Apabila terdapat pengaruh perlakuan, maka dilakukan uji lanjut yaitu uji beda nyata terkecil (BNT) untuk mengetahui perbedaan antar perlakuan 
(Steel dan Torie, 1991). Semua analisis kimia baik proksimat maupun kecernaan protein dilakukan dengan metode AOAC (1990).

HASIL DAN PEMBAHASAN

Pengaruh Perlakuan Terhadap Nilai Kandungan Proksimat Pada Bungkil Kedelai, Pollard dan Gaplek
Rataan kandungan proksimat yaitu kadar air, kadar abu, lemak kasar serat kasar dan protein kasar masingmasing perlakuan ditampilkan pada Tabel 1, Tabel 2 dan Tabel 3.

Tabel 1.

Hasil Analisis Kandungan Proksimat Pada Bungkil Kedelai

\begin{tabular}{|c|c|c|c|c|}
\hline \multirow{2}{*}{ Parameter } & \multirow{2}{*}{$\begin{array}{c}\text { Level } \\
\text { Kadar Air (A) }\end{array}$} & \multicolumn{2}{|c|}{ Lama Pengukusan (B) } & \multirow{2}{*}{ Rataan A } \\
\hline & & 15 Menit & 30 Menit & \\
\hline \multirow{3}{*}{ Kadar Air } & $25 \%$ & 22.21 & 12.67 & 17.44 \\
\hline & $50 \%$ & 32.1 & 17.84 & 24.97 \\
\hline & $75 \%$ & 34.59 & 5.4 & 19.995 \\
\hline & Rataan B & 29.63 & 11.97 & - \\
\hline \multirow{4}{*}{ Kadar Abu } & $25 \%$ & 9.69 & 14.84 & 12.265 \\
\hline & $50 \%$ & 8.996 & 11.66 & 10.328 \\
\hline & $75 \%$ & 9.29 & 10.87 & 10.08 \\
\hline & Rataan B & 9.32 & 12.45 & - \\
\hline \multirow{4}{*}{ Kadar Lemak Kasar } & $25 \%$ & 4.78 & 2.35 & 3.565 \\
\hline & $50 \%$ & 3.29 & 0.932 & 2.111 \\
\hline & $75 \%$ & 7.79 & 2.79 & 5.29 \\
\hline & Rataan B & 5.28 & 2.024 & - \\
\hline \multirow{4}{*}{ Kadar Serat Kasar } & $25 \%$ & 3.98 & 14.94 & 9.46 \\
\hline & $50 \%$ & 2.24 & 20.13 & 11.185 \\
\hline & $75 \%$ & 1.54 & 18.12 & 9.83 \\
\hline & Rataan B & 2.58 & 17.73 & - \\
\hline \multirow{4}{*}{ Kadar Protein Kasar } & $25 \%$ & 12.63 & 2.37 & 7.5 \\
\hline & $50 \%$ & 11.3 & 4.06 & 7.68 \\
\hline & $75 \%$ & 12.49 & 3.96 & 8.225 \\
\hline & Rataan B & 12.14 & 3.46 & - \\
\hline
\end{tabular}

Tabel 2.

Hasil Analisis Kandungan Proksimat Pada Pollard

\begin{tabular}{ccccc}
\hline \hline \multirow{2}{*}{ Parameter } & Level & \multicolumn{2}{c}{ Lama Pengukusan (B) } & \multirow{2}{*}{ Rataan A } \\
\cline { 2 - 4 } & Kadar Air (A) & 15 Menit & 30 Menit & \\
& $25 \%$ & 10.61 & 11.9 & 11.255 \\
Kadar Air & $50 \%$ & 46.17 & 19.76 & 32.965 \\
& $75 \%$ & 50.02 & 24.4 & 37.21 \\
\hline Kadar Abu & Rataan B & 35.6 & 18.68 & - \\
\hline & $25 \%$ & 9.76 & 8.05 & 8.905 \\
\hline
\end{tabular}




\begin{tabular}{ccccc}
\hline \hline \multirow{2}{*}{ Parameter } & Level & \multicolumn{2}{c}{ Lama Pengukusan (B) } & \multirow{2}{*}{ Rataan A } \\
\cline { 2 - 4 } & Kadar Air (A) & 15 Menit & 30 Menit & \\
\cline { 2 - 4 } & $50 \%$ & 10.19 & 8.14 & 9.165 \\
& $75 \%$ & 6.58 & 9.92 & 8.25 \\
\hline \multirow{3}{*}{ Kadar Lemak Kasar } & Rerata B & 8.84 & 8.7 & - \\
& $25 \%$ & 13.98 & 4.88 & 9.43 \\
& $50 \%$ & 8.33 & 6.11 & 7.22 \\
& $75 \%$ & 6.93 & 4.19 & 5.56 \\
\hline \multirow{3}{*}{ Kadar Serat Kasar } & Rerata B & 9.74 & 5.06 & - \\
& $25 \%$ & 25.28 & 35.73 & 30.505 \\
\hline & $50 \%$ & 18.94 & 25.03 & 21.985 \\
& $75 \%$ & 14.26 & 17.31 & 15.785 \\
\hline \multirow{3}{*}{ Kadar Protein Kasar } & Rerata B & 19.49 & 26.02 & - \\
& $25 \%$ & 14.78 & 2.76 & 8.77 \\
& $50 \%$ & 15.21 & 2.96 & 9.085 \\
\hline & $75 \%$ & 19.4 & 3 & 11.2 \\
\hline
\end{tabular}

Tabel 3.

Hasil Analisis Kandungan Proksimat Pada Gaplek

\begin{tabular}{ccccc}
\hline \hline \multirow{2}{*}{ Parameter } & Level & \multicolumn{2}{c}{ Lama Pengukusan (B) } & \multirow{2}{*}{ Rataan A } \\
\cline { 3 - 4 } & Kadar Air (A) & 15 Menit & 30 Menit & \\
& $25 \%$ & 10.61 & 11.9 & 11.255 \\
Kadar Air & $50 \%$ & 46.17 & 19.76 & 32.965 \\
& $75 \%$ & 50.02 & 24.4 & 37.21 \\
\hline & Rataan B & 35.6 & 18.68 & - \\
\hline \multirow{3}{*}{ Kadar Abu } & $25 \%$ & 6.29 & 5.67 & 5.98 \\
& $50 \%$ & 13.3 & 4.54 & 8.92 \\
& $75 \%$ & 6.21 & 4.18 & 5.195 \\
\hline & Rerata B & 8.6 & 4.79 & - \\
\hline \multirow{3}{*}{ Kadar Lemak Kasar } & $25 \%$ & 5.625 & 4.68 & 5.1525 \\
& $50 \%$ & 2.7 & 2.77 & 2.735 \\
& $75 \%$ & 3.14 & 4.51 & 3.825 \\
\hline \multirow{3}{*}{ Kadar Serat Kasar } & Rerata B & 3.82 & 3.98 & - \\
& $25 \%$ & 1.97 & 12.75 & 7.36 \\
& $50 \%$ & 2.95 & 18.05 & 10.5 \\
& $75 \%$ & 0.746 & 8.82 & 4.783 \\
\hline & Rerata B & 1.88 & 13.2 & - \\
\hline \multirow{2}{*}{ Kadar Protein Kasar } & $25 \%$ & 5.71 & 2.71 & 4.21 \\
& $50 \%$ & 7.05 & 2.75 & 4.9 \\
& $75 \%$ & 5.15 & 2.74 & 3.945 \\
\hline & Rerata A & 5.97 & 2.73 & - \\
\hline
\end{tabular}


Hasil analisis pada tabel diatas menunjukkan bahwa rataan kadar air, pada bungkil kedelai, pollard dan gaplek menunjukkan bahwa penambahan level kadar air dari 25, 50 dan 75\% dengan lama waktu pemanasan 15 dan 30 menit, mengalami peningkatan. Hasil perhitungan analisis ragam menunjukkan tidak terdapat pengaruh interaksi antara faktor A (level kadar air 25, 50 dan 75\%) dengan factor B (Lama Waktu pemanasan) terhadap nilai kandungan kadar air pada bungkil kedelai, pollard dan gaplek.

Kandungan kadar air bungkil kedelai, pollard dan gaplek (Tabel 1, Tabel 2 dan Tabel 3) mengalami perubahan menurunnya nilai kadar air pada setiap perlakuan penambahan level kadar air 20, 50 dan $75 \%$ dengan lama pemanasan 30 menit. Nilai kadar air pada lama pemanasan 30 menit menurun diduga karena faktor pemanasan yang lama sehingga jumlah air dalam bungkil kedelai menyusut. Hal ini sesuai dengan Lee dan Garlich (1992), mengatakan bahwa waktu pengukusan yang semakin lama dalam pengolahan akan berakibat semakin banyak terjadi hidrolisis, sehingga menurunnya kandungan air produk. Menurut Winarno dkk. (1980), penurunan kadar air pada pengolahan dengan uap akan diikuti dengan meningkatnya jumlah atau persentase bahan kering, sehingga akan merubah nilai zat-zat makanan lainnya seperti protein kasar, serat kasar dan lemak serta BETN.

Hasil analisis proksimat baik hasil dari data analisis dan perhitungan analisis ragam pada bahan pakan bungkil kedelai menunjukkan bahwa perlakuan tidak dapat meningkatkan nilai kadar abu, kadar lemak dan serat kasar. Pada pollard, penambahan level kadar air dan lama waktu pemanasan juga tidak berpengaruh nyata, namun menunjukan adanya penurunan pada kandungan lemak kasar dan serat kasarnya. Penurunan kandungan lemak kasar ini diduga disebabkan karena rusaknya molekul lemak melalui pemanasan. Nilai serat kasar juga relatif menurun akibat dari pemanasan. Hal ini diduga disebabkan karena pecahnya ikatan selulosa dan hemiselulosa pada serat, sehingga menghasilkan karbohidrat sederhana. Hal ini sesuai dengan pendapat Sutikno (2015), bahwa pemanasan secara steaming, dapat menyebabkan konversi selulosa dan hemiselulosa menjadi ikatan bentuk karbohidrat yang lebih sederhana. Menurut pendapat Tilman et al. (1998), kandungan serat kasar merupakan faktor pembatas lamanya waktu pencernaan sehingga mempengaruhi kecernaan dan akhirnya menurunkan tingkat kecernaan.

Penurunan lemak dan serat kasar juga terjadi pada tepung gaplek, yang diduga merupakan efek dari pemanasan. Diduga, pemanasan pada tepung gaplek juga mendegradasi kandungan lemak dan serat kasarnya.

\section{Pengaruh Perlakuan Terhadap Nilai Kandungan Kecernaan Protein Pada Bungkil Kedelei}

Rataan kandungan
protein masing-masing
ditampilkan pada Tabel 4, Tabel 5 dan
Tabel 6.


Tabel 4.

Hasil Analisis Kandungan Kecernaan Protein Pada Bungkil Kedelai

\begin{tabular}{ccccc}
\hline \multirow{2}{*}{ Lama Inkubasi } & \multirow{2}{*}{ Sampel } & \multicolumn{2}{c}{ Lama Waktu Pemanasan } & \multirow{2}{*}{ Rerata } \\
\cline { 2 - 4 } 0 jam & $25 \%$ & 54.00 & 59.00 & 56.5 \\
& $50 \%$ & 54.75 & 55.00 & 54.87 \\
& $75 \%$ & 53.5 & 57.00 & 55.25 \\
\hline \multirow{3}{*}{4 jam } & Rerata & 54.00 & 57.00 & \\
& $25 \%$ & 59.75 & 60.5 & 60.12 \\
& $50 \%$ & 59.75 & 59.5 & 59.62 \\
& $75 \%$ & 60.25 & 59.5 & 59.87 \\
\hline \multirow{3}{*}{8 jam } & Rerata & 59.16 & 59.83 & \\
& $25 \%$ & 61.00 & 61.5 & 61.25 \\
& $50 \%$ & 58.5 & 58.00 & 58.25 \\
& $75 \%$ & 60.00 & 59.5 & 59.75 \\
\hline \multirow{2}{*}{12 jam } & Rerata & 60.50 & 58.00 & \\
& $25 \%$ & 71.25 & 78.5 & 74.87 \\
& $50 \%$ & 71.75 & 78.00 & 74.87 \\
\hline & $75 \%$ & 72.00 & 79.00 & \\
\hline
\end{tabular}

Tabel 5.

Hasil Analisis Kandungan Kecernaan Protein Pada Pollard

\begin{tabular}{ccccc}
\hline \multirow{2}{*}{ Lama Inkubasi } & \multirow{2}{*}{ Sampel } & \multicolumn{2}{c}{ Lama Waktu Pemanasan } & \multirow{2}{*}{ Rerata } \\
\cline { 2 - 4 } 0 & 15 Menit & 30 Menit & \\
\hline \multirow{3}{*}{0 jam } & $25 \%$ & 73.5 & 9.5 & 41.5 \\
& $50 \%$ & 78.00 & 6.5 & 42.25 \\
& $75 \%$ & 81.5 & 10.00 & 45.75 \\
\hline \multirow{3}{*}{4 jam } & Rerata & 78.00 & 10.00 & \\
& $25 \%$ & 79.5 & 14.00 & 46.75 \\
& $50 \%$ & 81.5 & 33.00 & 57.25 \\
& $75 \%$ & 88.00 & 33.00 & 60.5 \\
\hline \multirow{3}{*}{8 jam } & Rerata & 88.00 & 26.67 & \\
& $25 \%$ & 84.5 & 16.5 & 50.5 \\
& $50 \%$ & 85.5 & 15.5 & 50.5 \\
& $75 \%$ & 86.5 & 13.5 & 50.00 \\
\hline \multirow{3}{*}{12 jam } & Rerata & 85.16 & 15.16 & \\
& $25 \%$ & 90.5 & 36.00 & 63.25 \\
& $50 \%$ & 91.00 & 36.5 & 63.75 \\
\hline & $75 \%$ & 90.5 & 39.00 & 64.75 \\
\hline
\end{tabular}


Tabel 6.

Hasil Analisis Kandungan Kecernaan Protein Pada Bungkil Gaplek

\begin{tabular}{|c|c|c|c|c|}
\hline \multirow{2}{*}{ Lama Inkubasi } & \multirow{2}{*}{ Sampel } & \multicolumn{2}{|c|}{ Lama Waktu Pemanasan } & \multirow[t]{2}{*}{ Rerata } \\
\hline & & 15 Menit & 30 Menit & \\
\hline \multirow{4}{*}{0 jam } & $25 \%$ & 53.00 & 4.5 & 28.75 \\
\hline & $50 \%$ & 43.00 & 5.5 & 24.25 \\
\hline & $75 \%$ & 39.5 & 2.00 & 20.75 \\
\hline & Rerata & 48.00 & 2.00 & \\
\hline \multirow{4}{*}{4 jam } & $25 \%$ & 64.00 & 9.00 & 36.5 \\
\hline & $50 \%$ & 70.00 & 13.00 & 41.5 \\
\hline & $75 \%$ & 59.00 & 13.5 & 36.25 \\
\hline & Rerata & 64.33 & 11.00 & \\
\hline \multirow{4}{*}{8 jam } & $25 \%$ & 61.00 & 13.5 & 37.25 \\
\hline & $50 \%$ & 70.00 & 17.00 & 43.5 \\
\hline & $75 \%$ & 61.00 & 21.00 & 41.00 \\
\hline & Rerata & 64.00 & 19.00 & \\
\hline \multirow{4}{*}{12 jam } & $25 \%$ & 63.00 & 37.5 & 50.25 \\
\hline & $50 \%$ & 73.00 & 38.00 & 55.5 \\
\hline & $75 \%$ & 63.00 & 37.00 & 50.00 \\
\hline & Rerata & 66.33 & 37.50 & \\
\hline
\end{tabular}

Hasil analisis data pada tabel rataan kecernaan protein diatas pada bungkil kedelai, pollard dan gaplek menunjukkan bahwa penambahan level kadar air dari 25, 50 dan $75 \%$ dengan lama waktu pemanasan 15 menit dan 30 menit dari inkubasi 0 jam, 4 jam, 8 jam dan 12 jam mengalami peningkatan, meskipun begitu hasil perhitungan analisis ragam menunjukkan bahwa tidak terdapat pengaruh yang sangat nyata antara faktor A (level kadar air 25, 50 dan 75\%) dengan B (Lama waktu pemanasan) terhadap nilai kandungan proksimat pada bungkil kedelai.

Kandungan kecernaan protein bungkil kedelai, pollard dan gaplek (Tabel 4, Tabel 5 dan Tabel 6) mengalami perubahan meningkatnya nilai kecernaan protein pada setiap perlakuan penambahan level kadar air 20, 50 dan $75 \%$ dengan lama pemanasan 15 menit dan 30 menit dari inkubasi $0,4,8$ dan 12 jam. Meningkatnya nilai kecernaan protein pada bahan pakan diduga karena faktor lamanya pemanasan dan disebabkan oleh adanya kombinasi perlakuan secara kimia dan fisik (fisiko-kimia). Hasil analisis data penelitian ini sesuai dengan Filawati (2003) bahwa kandungan zat-zat makanan yang diolah dengan cara pemanasan yaitu dikukus, menunjukan bahwa faktor waktu pengukusan memberikan perubahan peningkatan pada nilai kandungan zat makanan. Menurut pendapat Tilman et al (1998), tinggi rendahnya kecernaan protein dipengaruhi oleh kandungan protein pada bahan pakan ransum dan banyaknya protein yang masuk dalam saluran pencernaan.

Hal ini sesuai dengan pendapat Mirzah (1997) bahwa pemanasan dengan aoutoclave tidak banyak merubah komposisi zat-zat makanan pada bahan pakan, kecuali pada kualitas nutrisi zat-zat makanan akan meningkat terutama kecernaan protein dan retensi nitrogen serta kandungan khitinnya. 


\section{KESIMPULAN}

Berdasarkan hasil penelitian dapat disimpulkan bahwa kombinasi lama pengukusan dan penambahan level kadar air yang berbeda tidak berpengaruh terhadap nilai kandungan proksimat dan kecernaan protein baik pada bungkil kedelai, pollard dan juga gaplek. Manfaat dari penelitian ini adalah sebagai referensi informasi dalam berbagai upaya pengolahan bahan pakan untuk pembaca.
Saran dari penelitian ini adalah perlunya pengkajian ulang yang mendalam dan diskusi yang lebih fokus dalam menentukan kombinasi perlakuan agar perlakuan yang diterapkan mendapatkan hasil yang sesuai dengan kebutuhan ternak dilapangan. Penulis juga menyarankan agar dilakukan penelitian lebih lanjut tentang kombinasi perlakuan kompleks yang diterapkan dalam pengolahan bahan pakan. 
DAFTAR PUSTAKA

A.O.A.C. 1990. Official Methods Of Analysis, $15^{\text {th }}$ Ed. A.O.A.C., Arlington, Vol. II, 1990: a) Method 988.15, Tryptophan in Foods and Feed Ingredients, p.1101. b) Method 985.28, Sulfur Amino Acids in Foods and Feed Ingredients, p.1102.

Filawati. 2003. Pengolahan Limbah Udang

Secara Fisika-kimia dan Pengaruh

Pemanfaatannya dalam Ransum

Terhadap Penampilan Produksi Ayam Petelur. Thesis, Program Pascasarjana Universitas Andalas, Padang.

Hartadi H., S. Reksohadiprojo, AD. Tilman. 1997. Tabel Komposisi Pakan Untuk Indonesia. Cetakan Keempat. Gajah Mada University Press, Yogyakarta.

Lee, H and J. D. Garlich. 1992. Efect Of Overcooked Souybea Meal On Chicken Performance And Amino Acid Availability. Poultry Science $71: 499-508$.

McDonald $\mathrm{P}$ at al. 1995. Animal Nutrition. Ed ke-5. New York: Longman Scientific and Technical. Mirzah. 2004. Peningkatan Bioavailability Limbah Udang Melalui Pengolahan dan Pemanfaatannya Sebagai Pakan Pengganti TepungIkan Dalam Ransum Ternak Unggas. Laporan Penelitian Universitas Andalas, Padang.

Mirzah dan Filawati. 2013. Pengolahan Limbah Udang Untuk Memperoleh Bahan Pakan Sumber Protein Hewani Pengganti Tepung Ikan. Jurnal Peternakan Indonesia. 15: 1907-1760.

Ravindran, V dan R. Blair. 1991. Feed

Resources For Poultry Production in Asia and The Pasific. Plant Protein Sources. W. Poult. Sci. J. $48: 205-231$.
Rasyaf, M. 1994. Makanan Ayam Broiler. Kanisius, Yogyakarta.

Ridwan, A. A. 2006. PerubahanPerubahan Protein yang Diakibatkan oleh Proses Pengolahan pada Daging Domba. Departemen Ilmu Produksi dan Teknologi Peternakan, Fakultas Peternakan, Institut Pertanian Bogor, Bogor. (Skripsi Sarjana Peternakan).

Soejono, M., R. Utomo dan Widyantoro. 1987. Peningkatan Nilai Nutrisi Jerami Padi dengan Berbagai Perlakuan (Rangkuman). Dalam : Limbah Pertanian Sebagai Pakan dan Manfaat Lainnya. M. Soejono, A. Musofie. R. Utomo, N. K. Wardhani. J. B Schiere (ed.). Proceedings Bioconversion Project Second Workshop on Crop Residues for Feed and Other Purposes. Grati.

Sunarso, 1984. Mutu Protein Limbah Agro-Industri Ditinjau dari kinetika Perombakannya oleh Mikroba Rumen dan Potensinya bagi Pencernaan Pasca Rumen. Institut Pertanian Bogor, Bogor (Tesis).

Sutardi, T. 1981. Sapi Perah dan Pemberian Makananya. Dep0artemen Ilmu Makanan Ternak. Fakultas Istitute Pertanian Bogor, Bogor. (tidak diterbitkan).

Sutikno, Marniza dan M. F. Yanti. 2015. Pengaruh Perlakuan Awal Basa dan Asam Terhadap Kadar Glukosa Reduksi Tandan Kosong Kelapa Sawit. Jurnal Teknologi Industri dan Hasil Pertanian 20 (1) : $1-10$.

Steel, R.G.D., dan J. H. Torrie. 1991. Prinsip Dan Prosedur Statistika, Suatu Pendekatan Biometrik. P.T. Gramedia Pustaka Utama, Jakarta. 
Utama, C.S., B. Sulistiyanto, and S. Kismiati. 2017. The effects of water addition and steaming duration on starch composition of wheat pollard. Reaktor. 17(4): 220224.

Tillman, D. A., H. Hartadi., S. Reksohadiprojo, S. Lebdosoekojo.
1998. Ilmu Makanan Ternak Dasar. Gajah Mada University Press, Yogyakarta.

Winarno, F. G dan D. Fardiaz. 1980. Penanganan Teknologi Pangan. PT. Gramedia, Jakarta. 